\title{
Comparative nutritional analysis for different varieties of Chinese dwarf cherry (Cerasus humilis (Bge.) Sok)
}

\author{
Kehong Liang ${ }^{1, *}$, Hong Zhu ${ }^{1}$, Xin Zhao ${ }^{1}$, Xue Chen $^{1}$, Dongxia Ma ${ }^{1}$, Tong Wang ${ }^{1}$, Jing Wang ${ }^{1}$ \\ ${ }^{1}$ Institute of Food and Nutrition Development, Ministry of Agriculture and Rural Affairs, Beijing, China
}

\begin{abstract}
Macrounutrients (protein, moisture, ash, dietary fiber), vitamin E, Vitamin C, mineral elements (K, Ca, Mg, Zn, Fe, Mn), six soluble sugars (fructose, glucose, sucrose, galactose, xylose, arabinose) and four organic acids (oxalic, succinic, tartaric, malic acid) were studied in five varieties of Chinese dwarf cherry (Cerasus humilis (Bge.) Sok) for the first time. The results indicated that Chinese dwarf cherry offers a rich source of minerals, especially $\mathrm{Ca}$ and $\mathrm{Fe}$, with the Ca content was 8-10 times that of apples, and $\mathrm{K}$ content was 5-20 times that of apples. In addition, Chinese dwarf cherry was also a provider of vitamin C, sucrose, and malic acid. Our result provides a theoretical basis for the comprehensive utilization and development of Chinese dwarf cherry.
\end{abstract}

\section{Introduction}

Chinese dwarf cherry (Cerasus humilis (Bge.) Sok.) is a shrub of the family Rosaceae that originated in Northwest China ${ }^{[1]}$. Chinese dwarf cherry, as a unique fruit resource in China, has strong ecological value. It shows resistance to cold, drought, barren soil and high salt ${ }^{[2]}$. The fruit of Chinese dwarf cherry contains many nutrients and active compounds, including minerals, sugars, organic acids, volatile components, and flavonoids ${ }^{[3-7]}$. They can not only be consumed fresh, but can also be processed into other products, such as wine, vinegar, jam and other products ${ }^{[8]}$. Therefore, the quality of the fruits quality, especially the composition and content of active components, has an important impact on the Chinese dwarf cherry industry. With the development of people's fruit consumption concept from quantity demand to the demand for the nutritional value of fruit. Due to the extremely high economic value and nutritional value of Chinese dwarf cherry, it has attracted more and more attention from researchers.

The quality of Chinese dwarf cherry fruit is a key factor in determining the economic value of fruits. Chinese dwarf cherry fruit is called "calcium fruit" because of its high calcium content, and has a unique aroma as well as a sweet and sour taste. It is a rich source of nutrients, minerals, soluble sugars and organic acids. However, the differences in the nutrient compositions of Chinese dwarf cherry have not yet been clarified.

In this study, we aimed to evaluate the differences in the nutritional components, especially the compostition and concentration of soluble sugars and minerals, in different varieties of Chinese dwarf cherry. The results will provide a theoretical reference for consumption of fresh fruits or industrial processing.

\section{Materials and methods}

\subsection{Materials}

Five varieties of Chinese dwarf cherry (Cerasus humilis (Bge.) Sok) (referred as number 1-5) were harvested from Wendeng city Shandong provinces $\left(37^{\circ} \mathrm{N}, 122^{\circ} \mathrm{E}\right)$ in 2019. All varieties received the same level of fertilization, irrigation, pruning, and disease management. Following harvest, half of samples were immediately analysed for its physical properties and the rest stored at $-80^{\circ} \mathrm{C}$ until subsequent analysis. Three replicate samples of fruit were collected from three trees of each varieties.

\subsection{Experimental methods}

\subsubsection{Proximate Composition}

Crude protein, moisture and ash contents were determined using standard methods ${ }^{[9-10]}$. Dietary fiber was estimated using the methods of Englyst and Hudson $^{[11]}$.

\subsubsection{Multi-element Analysis}

Chinese dwarf cherry samples were analyzed after microwave digestion using MARS (CEM Company) microwave digestion system. $0.2 \mathrm{~g}$ of sample, $10 \mathrm{~mL}$ of $65 \% \mathrm{HNO}_{3}$, and $1 \mathrm{~mL}$ of hydrogen peroxide solution (31\%) were added into a PTFE digestion tube and digested for $40 \mathrm{~min}$ by increasing the power to $1600 \mathrm{~W}$ and the temperature to $210^{\circ} \mathrm{C}$ in a stepwise fashion. The

\footnotetext{
* Corresponding author: liangkehong @ caas.cn
} 
digested solution was diluted to $50 \mathrm{~mL}$ with ultra pure water and stored in a plastic flask before analysis.

Multi-elements were measured using Inductively Coupled Plasma Mass Spectrometry (ICP-MS, X Series 2, Thermo Fisher, America). Standard solutions for K, $\mathrm{Ca}, \mathrm{Mg}, \mathrm{Zn}, \mathrm{Fe}$ and $\mathrm{Mn}$ were prepared using multielement calibration standard solutions, and all determination coefficients of the standard curves were higher than 0.99. Because there is no matching certified reference material (CRM) for millets, the analytical quality control was routinely validated using a rice reference material, GSB-1 (GWB 10010). The recovery and the relative standard deviation (RSD) of these 6 elements in fruits were found to be higher than $90 \%$ and lower than $10 \%$, respectively.

\subsubsection{Vitamin E and Vitamin C Analysis}

The vitamin $\mathrm{E}$ in the fruit was assessed as per the National Standards for the Determination of Vitamin A, $\mathrm{D}$, and $\mathrm{E}$ in Foods ${ }^{[12]}$. The vitamin $\mathrm{C}$ in fruit was assessed as per the National Standards for Determination of Vitamin $C^{[13]}$.

\subsubsection{Soluble Sugar Analysis}

Soluble sugars were determined by 850 Professional IC equipped with 871 Advanced Bioscan. IC separation was performed on a Metrosep Carb 1 column $(5.0 \mu \mathrm{m}, 150$ $\mathrm{mm} \times 4.0 \mathrm{~mm}$ ) with a Metrosep guard column. The isocratic mobile phase was consisted of solvent A (250 $\mathrm{mmol} / \mathrm{L} \mathrm{NaOH})$ and solvent $\mathrm{B}\left(\mathrm{H}_{2} \mathrm{O}\right)$ at a ratio of 40:60. The flow rate for mobile phase solution was $1 \mathrm{~mL} / \mathrm{min}$. The eluted analytes were detected and quantified by an 871 Advanced Bioscan with PAD mode. Gold electrode and $\mathrm{Ag} / \mathrm{AgCl}$ electrode were used as working electrode and reference electrode, respectively.

\subsubsection{Organic Acid Analysis}

The organic acid compositions of fruits were analysed using the HPLC system (Model 1200, Agilent Technologies, Palo Alto, CA, USA) using a C18 column $(250 \mathrm{~mm} \times 4.6 \mathrm{~mm}, 5 \mu \mathrm{m}$ particle size $)$. Chromatographic separation was performed at $40^{\circ} \mathrm{C}$ at a flow rate of $0.8 \mathrm{ml} / \mathrm{min}$. The mobile phase was a 95:5 $(\mathrm{v} / \mathrm{v})$ mix of $0.02 \mathrm{M} \mathrm{KH}_{2} \mathrm{PO}_{4}$ and $100 \%$ methanol. The $\mathrm{KH}_{2} \mathrm{PO}_{4}$ had been adjusted to $\mathrm{pH} 2.6$ with $\mathrm{H}_{3} \mathrm{PO}_{4} .8 \mu \mathrm{l}$ of each extract sample was injected for HPLC analysis. The absorbance of the eluate was measured at $210 \mathrm{~nm}$.

\subsubsection{Statistical analysis}

The statistical analysis was performed using SPSS 19.0 software (SPSS Inc., Chicago, IL, USA), while differences between means were determined using Dunnet's test and considered extremely significant when $\mathrm{P}<0.05$.

\section{Results and Discussion}

\subsection{Chemical composition in fruit samples}

The chemical composition of millet samples is shown in Table 1. Moisture, protein, fat, ash, dietary fiber content were significantly different $(\mathrm{P}<0.05)$ among the samples from different varieties. The moisture content of No. 2 was $86.32 \mathrm{~g} / 100 \mathrm{~g} \mathrm{FW}$, higher than No. 3 and No. 4 . The protein content of No. 5 was higher $(1.35 \mathrm{~g} / 100 \mathrm{~g} \mathrm{FW})$ in fruit than other varieties. The protein content of No.1 was slightly lower than that of No.5, which was 1.27 $\mathrm{g} / 100 \mathrm{~g}$. The ash content of No.3 was the highest, which was equivalent to that of No.4 and No.5, and it was significantly different from No.1 and No.2. Chinese dwarf cherry could be used as a good resource for dietary fiber ${ }^{[13]}$. The dietary fiber of No.4 was the highest and the lowest was No.2.

Table 1 Macronutrients content in five varieties of Chinese dwarf cherry ( $\mathrm{g} / 100 \mathrm{~g} \mathrm{FW})$. Means in the same column with different superscripts are significantly different $(\mathrm{P}<0.05)$.

\begin{tabular}{ccccc}
\hline Varieties & Moisture & Protein & Ash & Dietary fiber \\
\hline No.1 & $82.03^{\mathrm{b}}$ & $1.27^{\mathrm{b}}$ & $0.76^{\mathrm{b}}$ & $5.26^{\mathrm{a}}$ \\
No.2 & $86.32^{\mathrm{a}}$ & $0.93^{\mathrm{d}}$ & $0.73^{\mathrm{b}}$ & $2.97^{\mathrm{c}}$ \\
No.3 & $84.20^{\mathrm{a}}$ & $1.02^{\mathrm{c}}$ & $1.48^{\mathrm{a}}$ & $3.17^{\mathrm{c}}$ \\
No.4 & $81.21^{\mathrm{ab}}$ & $0.93^{\mathrm{d}}$ & $1.41^{\mathrm{a}}$ & $5.38^{\mathrm{a}}$ \\
No.5 & $82.13^{\mathrm{b}}$ & $1.35^{\mathrm{a}}$ & $1.42^{\mathrm{a}}$ & $4.82^{\mathrm{b}}$ \\
\hline
\end{tabular}

\subsection{Mineral elements in fruit samples}

$\mathrm{K}$, $\mathrm{Ca}$ and $\mathrm{Mg}$ were essential macro metal elements and $\mathrm{Zn}, \mathrm{Fe}, \mathrm{Mn}$ were the trace elements for the human body. As shown the Table 2, the order of the content of several mineral elements in Chinese dwarf cherry fruit was: $\mathrm{K}>$ $\mathrm{Mg}>\mathrm{Ca}>\mathrm{Fe}>\mathrm{Mn}>\mathrm{Zn}$. The six mineral elements $(\mathrm{K}, \mathrm{Ca}$, $\mathrm{Mg}, \mathrm{Zn}, \mathrm{Fe}$ ) content of No.1 and No.5 fruit were relatively high.

Among them, there was no significant difference in the $\mathrm{K}$ content of No.1 and No.5 fruit, but both were higher than the other three fruits. The Ca content of No.1, No.2, No.5 were $47.30 \mathrm{mg} / \mathrm{kg}, 44.30 \mathrm{mg} / \mathrm{kg}$ and 45,40 $\mathrm{mg} / \mathrm{kg}$, respectively. There was no significant difference in the $\mathrm{Ca}$ content of the three samples, but all higher than No.3 and No.4 samples. Chinese dwarf cherry was known as calcium fruit, and its calcium content was about 8-10 times that of apples. The Mg content of No.5 was the highest, at $98.9 \mathrm{mg} / \mathrm{kg}$, and it was significantly different from other Chinese dwarf cherry fruit. The $\mathrm{Mg}$ content of No.1 fruit was the second $(80.95 \mathrm{mg} / \mathrm{kg})$. The $\mathrm{Mg}$ content of No.3 fruit was $23.2 \mathrm{mg} / \mathrm{kg}$, which was the least among the five varieties. The $\mathrm{Zn}$ content of No.1 and No.5 were the highest, and both of which were 2.02 $\mathrm{mg} / \mathrm{kg}$. The $\mathrm{Zn}$ content in No.4 was $1.03 \mathrm{mg} / \mathrm{kg}$, which was the least content among the five vateties. As shown in Table 2, the iron content of Chinese dwarf cherry was 5-20 times that of apple. The Fe content of No.4 was $11.8 \mathrm{mg} / \mathrm{kg}$, which was significantly higher than the $\mathrm{Fe}$ 
content in the other four fruits. The Fe content in No.2 and No.4 fruit were the least, $3.64 \mathrm{mg} / \mathrm{kg}$ and $3.42 \mathrm{mg} / \mathrm{kg}$ respectively.

Table 2 Mineral content in five varieties of Chinese dwarf cherry (mg/kg FW). Means in the same column with different superscripts are significantly different $(\mathrm{P}<0.05)$.

\begin{tabular}{ccccccc}
\hline Varieties & $\mathrm{K}$ & $\mathrm{Ca}$ & $\mathrm{Mg}$ & $\mathrm{Zn}$ & $\mathrm{Fe}$ & $\mathrm{Mn}$ \\
\hline No.1 & $2.12 \times 10^{3 \mathrm{a}}$ & $47.30^{\mathrm{a}}$ & $80.95^{\mathrm{b}}$ & $2.02^{\mathrm{a}}$ & $11.8^{\mathrm{a}}$ & $4.00^{\mathrm{b}}$ \\
No.2 & $1.70 \times 10^{3 \mathrm{~b}}$ & $44.30^{\mathrm{a}}$ & $39.00^{\mathrm{d}}$ & $1.34^{\mathrm{b}}$ & $3.64^{\mathrm{d}}$ & $3.09^{\mathrm{c}}$ \\
No.3 & $1.72 \times 10^{3 \mathrm{~b}}$ & $33.50^{\mathrm{b}}$ & $23.20^{\mathrm{e}}$ & $1.30^{\mathrm{b}}$ & $4.26^{\mathrm{c}}$ & $4.14^{\mathrm{a}}$ \\
No.4 & $1.71 \times 10^{3 \mathrm{~b}}$ & $35.40^{\mathrm{b}}$ & $62.60^{\mathrm{c}}$ & $1.03^{\mathrm{c}}$ & $3.42^{\mathrm{d}}$ & $3.96^{\mathrm{b}}$ \\
No.5 & $2.23 \times 10^{3 \mathrm{a}}$ & $45.40^{\mathrm{a}}$ & $98.90^{\mathrm{a}}$ & $2.02^{\mathrm{a}}$ & $9.66^{\mathrm{b}}$ & $1.98^{\mathrm{d}}$ \\
\hline
\end{tabular}

\subsection{Vitamin E and Vitamin C in fruit samples}

The tocopherol profiles of Chinese dwarf cherry are presented in Table 3. Tocopherols $(\alpha, \beta, \gamma$, and $\delta)$ and their various tocotrienols constitute vitamin $E^{[15]}$. Vitamin $\mathrm{E}$ is a natural lipid-soluble antioxidant considered to be the most effective in protecting cell membranes from mutagenic nitrogen oxides and peroxyl radicals ${ }^{[16]}$. In the present work, three tocopherols $(\alpha, \gamma$, and $\delta$ ) were found in all the samples. Significant differences were apparent between the five samples. In general, fruit presents mainly $\alpha$-tocopherol (0.99-3.39 $\mathrm{mg} / 100 \mathrm{~g} \mathrm{FW})$, followed closely by $\gamma$-tocopherol $(0.21$ $39 \mathrm{mg} / 100 \mathrm{~g})$, and $\delta$-tocopherol (0.05-0.12 mg/100 g). The individual and total tocopherols varied substantially among the different varieties. $\alpha$-Tocopherol was mostly found in No.1 fruit $(3.39 \mathrm{mg} / 100 \mathrm{~g})$, while No.2, No.5, No. 5 fruit presented the lowest values. $\gamma$-Tocopherol was mostly found in No.5 fruit $(0.39 \mathrm{mg} / 100 \mathrm{~g})$, as well as No.4 fruit $(0.34 \mathrm{mg} / 100 \mathrm{~g})$. The $\delta$-Tocopherol content of No.4 were the higher in fruit than other varieties. Therefore, it is suggested that the tocopherol profile of Chinese dwarf cherry can be impacted by varieties.

There were significant differences in the VC content between different varieties of Chinese dwarf cherry. Among them, VC was mostly found in No.5 fruit (41.27 $\mathrm{mg} / 100 \mathrm{~g} \mathrm{FW}$ ), while No.2 presented the lowed values. The result was higher than that of Zhang et al. ${ }^{[17]}$, probably because the varieties of fruit were different.

Table 3 Vitamins in five varieties of Chinese dwarf cherry (mg/100 g FW). Means in the same column with different superscripts are significantly different $(\mathrm{P}<0.05)$

\begin{tabular}{cccccc}
\hline Varieties & VE & $\alpha$ - Tocopherol $\gamma$ - Tocopherol $\delta$ - Tocopherol & VC \\
\hline No.1 & $3.72^{\mathrm{a}}$ & $3.39^{\mathrm{a}}$ & $0.23^{\mathrm{b}}$ & $0.10^{\mathrm{b}}$ & $17.80^{\mathrm{b}}$ \\
No.2 & $1.30^{\mathrm{c}}$ & $0.99^{\mathrm{c}}$ & $0.25^{\mathrm{b}}$ & $0.06^{\mathrm{c}}$ & $8.75^{\mathrm{d}}$ \\
No.3 & $1.46^{\mathrm{c}}$ & $1.17^{\mathrm{c}}$ & $0.21^{\mathrm{b}}$ & $0.08^{\mathrm{c}}$ & $12.70^{\mathrm{c}}$ \\
No.4 & $2.07^{\mathrm{b}}$ & $1.61^{\mathrm{b}}$ & $0.34^{\mathrm{a}}$ & $0.12^{\mathrm{a}}$ & $10.67^{\mathrm{c}}$ \\
No.5 & & $1.05^{\mathrm{c}}$ & $0.39^{\mathrm{a}}$ & $0.05^{\mathrm{c}}$ & $41.27^{\mathrm{a}}$ \\
& $1.50^{\mathrm{c}}$ & & & & \\
\hline
\end{tabular}

\subsection{Soluble sugar in fruit samples}

The level of soluble sugar content in fruit of Chinese dwarf cherry was a key indicator that affected its flavor and quality. The fructose, glucose, sucrose, galactose, xylose and arabinose in the fruit of Chinese dwarf cherry were shown in Table 4 . The soluble sugar content was significantly different between different varieties, and the sugar with highest content was generally found to be sucrose followed by glucose, fructose, xlylose, galactose, arabinose, respectively.

Compared with other fruits, Chinese dwarf cherry can be used as a source of sucrose ${ }^{[8]}$. Sucrose content of fruits varied from $0.40-4.95 \mathrm{~g} / 100 \mathrm{~g} \mathrm{FW}$, with the maximum and minimum values observed in No.5 and No.2, respectively. The results was consistent with the Mo et al. [8]. The highest and lowest contents of glucose were observed in No.4 and No.1, respectively, while for fructose the respective varieties were No.2 and No.1. The glucose and fructose contents found in Chinese dwarf cherry samples in this study were lower than that detected in sweet cherry ${ }^{[18]}$.

Table 4 Soluble sugar in five varieties of Chinese dwarf cherry. Means in the same line with different superscripts are significantly different $(\mathrm{P}<0.05)$

\begin{tabular}{cccccc}
\hline Varieties & No.1 & No.2 & No.3 & No.4 & No.5 \\
\hline $\begin{array}{c}\text { Fructose } \\
(\mathrm{g} / 100 \mathrm{~g} \mathrm{FW}) \\
\text { Glucose }\end{array}$ & $0.18^{\mathrm{e}}$ & $1.26^{\mathrm{a}}$ & $1.00^{\mathrm{b}}$ & $0.76^{\mathrm{c}}$ & $0.33^{\mathrm{d}}$ \\
$\begin{array}{c}\mathrm{g} / 100 \mathrm{~g} \mathrm{FW}) \\
\text { Sucrose }\end{array}$ & $0.80^{\mathrm{c}}$ & $1.14^{\mathrm{ab}}$ & $1.27^{\mathrm{ab}}$ & $1.57^{\mathrm{a}}$ & $1.23^{\mathrm{ab}}$ \\
$\begin{array}{c}\text { (g/100g FW) } \\
\text { Galactose } \\
(\mathrm{mg} / 100 \mathrm{~g} \mathrm{FW})\end{array}$ & $3.44^{\mathrm{b}}$ & $0.40^{\mathrm{c}}$ & $4.75^{\mathrm{a}}$ & $3.87^{\mathrm{b}}$ & $4.95^{\mathrm{a}}$ \\
$\begin{array}{c}\text { Xylose } \\
(\mathrm{mg} / 100 \mathrm{~g} \mathrm{FW})\end{array}$ & $41.6^{\mathrm{b}}$ & $10.2^{\mathrm{ab}}$ & $9.3^{\mathrm{b}}$ & $9.1^{\mathrm{b}}$ & $7.4^{\mathrm{c}}$ \\
$\begin{array}{c}\text { Arabinose } \\
(\mathrm{mg} / 100 \mathrm{~g} \mathrm{FW})\end{array}$ & $0.6^{\mathrm{a}}$ & $0.6^{\mathrm{a}}$ & $38.2^{\mathrm{c}}$ & $42.9^{\mathrm{b}}$ & $67.5^{\mathrm{a}}$ \\
\hline
\end{tabular}

\subsection{Organic acids in fruit samples}

Oxalic, succinic, tartaric and malic acid contents in the fruit of Chinese dwarf cherry are shown in Table 5. The predominant organic acid in Chinese dwarf cherry was malic acid, followed by tartaric oxalic succinic acid, respectively.

Malic acid contents in all five fruit samples ranged from $1.216 \mathrm{~g} / 100 \mathrm{~g} \mathrm{FW}$ in No.2 fruit, to $2.690 \mathrm{~g} / 100 \mathrm{~g}$ FW in No.5 fruit. Malic acid contents were higher than reported by Mo et al. ${ }^{[8]}$, but lower than in cornelian cherry ${ }^{[19]}$. The highest and lowest tartaric acid contents were observed in varieties No.3 and No.4, respectively. The oxalic acid contents ranged from 0.021-0.078 g/100 g FW, while succinic acid contents in Chinese dwarf cherry varied from $0.001-0.007 \mathrm{~g} / 100 \mathrm{~g} \mathrm{FW}$. The oxalic acid contents were higher than that in sweet cherry [20], and succinic acid contents were lower than pear and orange ${ }^{[21]}$.

Table 5 Organic acids in five varieties of Chinese dwarf cherry (g/100 g FW). Means in the same column with different superscripts are significantly different $(\mathrm{P}<0.05)$

\begin{tabular}{ccccc}
\hline \multirow{2}{*}{ Varieties } & $\begin{array}{c}\text { Oxalic } \\
\text { acid }\end{array}$ & $\begin{array}{c}\text { Succinic } \\
\text { acid }\end{array}$ & $\begin{array}{c}\text { Tartaric } \\
\text { acid }\end{array}$ & $\begin{array}{c}\text { Malic } \\
\text { acid }\end{array}$ \\
\hline
\end{tabular}




\begin{tabular}{lllll}
\hline No.1 & $0.078^{\mathrm{a}}$ & $0.001^{\mathrm{b}}$ & $0.433^{\mathrm{c}}$ & $2.386^{\mathrm{a}}$ \\
No.2 & $0.071^{\mathrm{a}}$ & $0.007^{\mathrm{a}}$ & $0.521^{\mathrm{b}}$ & $1.216^{\mathrm{d}}$ \\
No.3 & $0.021^{\mathrm{b}}$ & $0.001^{\mathrm{b}}$ & $0.700^{\mathrm{a}}$ & $1.814^{\mathrm{b}}$ \\
No.4 & $0.031^{\mathrm{b}}$ & $0.001^{\mathrm{b}}$ & $0.414^{\mathrm{c}}$ & $1.505^{\mathrm{c}}$ \\
No.5 & $0.030^{\mathrm{b}}$ & $0.001^{\mathrm{b}}$ & $0.463^{\mathrm{c}}$ & $2.690^{\mathrm{a}}$ \\
\hline
\end{tabular}

\section{Conclusions}

Macrounutrients (protein, moisture, ash, dietary fiber), vitamin $\mathrm{E}$, Vitamin $\mathrm{C}$, mineral elements $(\mathrm{K}, \mathrm{Ca}, \mathrm{Mg}, \mathrm{Zn}$, $\mathrm{Fe}, \mathrm{Mn}$ ), six soluble sugars (fructose, glucose, sucrose, galactose, xylose, arabinose) and four organic acids (oxalic, succinic, tartaric, malic acid) were studied in five varieties of Chinese dwarf cherry for the first time. The results indicated that Chinese dwarf cherry offers a rich source of minerals, especially $\mathrm{Ca}$ and $\mathrm{Fe}$, with the Ca content was 8-10 times that of apples, and $\mathrm{K}$ content was 5-20 times that of apples. In addition, Chinese dwarf cherry was also a provider of vitamin C, sucrose, and malic acid. This research provides a theoretical basis for the comprehensive utilization and development of Chinese dwarf cherry.

\section{Acknowledgment}

This research was supported by Science and Technology Innovation Project of Chinese Academy of Agricultural Sciences (CAAS-ASTIP-2020-7).

\section{References}

1. H.B. Shao, L.Y. Chu, Biomass Bioenerg 32, (2008)

2. Z.P. Yin, J. Ren, L. J. Zhou, L.N. Sun, J. W. Wang, Y.L. Liu, X.S. Song, Proteome Sci 15, 9 (2016)

3. M.L. Zhang, Q.C. Deng, H.X. Yang, Z.Y. Zhang, Amino Acids \& Biotic Resources 29, (2007)

4. L. Chen, X.L. Xin, Q.P. Yuan, D.H. Su, W. Liu, J. Sci. Food Agric 94, 2 (2014)

5. W.D. Li, O. Li, C. Mo, Y.S. Jiang, Y. He, A.R. Zhang, L.M. Chen, J.S. Jin, J Hortic Sci Biotechnol 89, 6 (2014)

6. S.W. Liu, X.Y. Li, Z.Y. Guo, X. Zhang, X.D. Chang, J. Food Qual 11, (2018)

7. X.P. Mu, P.F. Wang, J.J. Du, Y.G. Gao, J.C. Zhang. PLoS One 13, 4 (2018)

8. C. Mo, W.D. Li, Y.X. He, L.O. Ye, Z.S. Zhang, J.S. Jin, J. Hortic. Sci. Biotech 90, 4 (2015)

9. GB 5009.3-2010, National Standard of the People's Republic of China: Beijing, China. (2010)

10. GB 5009.4-2010, National Standard of the People's Republic of China: Beijing, China. (2010)

11. H.N. Englyst, G.J. Hudson, Food Chem 57, (1996)

12. GB 5009.82-2016 National Standard of the People's Republic of China: Beijing, China. (2010).

13. GB 5009.86-2016 National Standard of the People's Republic of China: Beijing, China. (2010).
14. D.W. Wang, N. Li, X. Zhao, Food Sci 37, 7 (2016)

15. C. Schneider, Mol. Nutr. Food Res 49, (2005)

16. S.M.F. Bessada, R.C. Alves, A.S.G. Costa, M.A. Nunes, M.B.P.P. Oliveira, Sci. Total. Environ 645, (2018)

17. Y.Q. Zhang, Q. Si, R. Zhai, Y.B. Zhou, X. Zhang, Food Res Develop 38, (2017)

18. G. Ballistreri, A. Continella, A. Gentile, M. Amenta, S. Fabroni, P. Rapisarda, Food Chem 140, (2013)

19. P. Drkenda, A. Spahic, A. Begic-Akagic, F. Gasi, A. Vranac, M. Hudina, M. Blanke, Erwerbs-Obstbam $56,(2014)$

20. V. Usenik, J. Fabcic, F. Stampar, Food chem 107, (2008)

21. M. Li, L.H. Feng, J.X. Yun, H.L. Zhang, N. Li, Sci Tech Food Ind 9, (2009) 